\title{
Jurnal Keolahragaan
}

Volume 3 - Nomor 2, September 2015, (164 - 177)

Tersedia online: http://journal.uny.ac.id/index.php/jolahraga

\section{MODEL PERMAINAN AKTIVITAS LUAR KELAS UNTUK MENGEMBANGKAN RANAH KOGNITIF, AFEKTIF, DAN PSIKOMOTORIK SISWA SMA}

\author{
Hendra Setyawan ${ }^{1)}$, Dimyati ${ }^{2)}$ \\ Dinas Pendidikan dan Kebudayaan Kabupaten Pelalawan Riau ${ }^{1)}$, Universitas Negeri Yogyakarta ${ }^{2)}$ \\ hendra_abdullah7777@yahoo.co.id ${ }^{1)}$,dimy_rismi@yahoo.com ${ }^{2)}$
}

\begin{abstract}
Abstrak
Penelitian ini bertujuan menghasilkan model-model permainan Aktivitas Luar kelas (ALK) yang layak digunakan sebagai materi pembelajaran penjas, serta efektif untuk mengembangkan ranah kognitif, afektif, dan psikomotorik siswa SMA. Penelitian ini dilakukan dengan langkah-langkah sebagai berikut: (1) pengumpulan informasi di lapangan, (2) menganalisis informasi yang telah dikumpulkan, (3) mengembangkan produk awal, (4) validasi ahli dan revisi, (5) uji coba skala kecil dan revisi, (6) uji coba skala besar dan revisi, dan (7) pembuatan produk final. Uji coba skala kecil dilakukan terhadap siswa kelas X-D dan XI-IPA 4 dari SMA N I Prambanan berjumlah 66 orang. Uji coba skala besar dilakukan terhadap siswa kelas X-G, X-H, XI-IPS 3, dan XI-BHS dari SMA N I Prambanan berjumlah 132 orang. Instrumen pengumpulan data yang digunakan yaitu; (1) pedoman wawancara, (2) skala nilai, (3) pedoman observasi permainan, (4) pedoman observasi keefektifan permainan, (5) pedoman observasi terhadap guru pelaku uji coba, dan (6) rubrik penilaian siswa. Teknik analisis data dengan analisis deskriptif kuantitatif dan kualitatif. Hasil penelitian berupa tujuh model permainan yang layak dan efektif digunakan dalam pembelajaran penjas, hal ini dibuktikan dengan perolehan persentase sebesar $100 \%$ dari data hasil kuesioner skala nilai, observasi model permainan, observasi keefektifan permainan, dan observasi guru pelaku uji coba. Model permainan juga efektif untuk mengembangkan ranah kognitif, afektif, dan psikomotorik, yang dibuktikan dengan terjadinya peningkatan persentase nilai rata-rata siswa sebesar $21 \%$.
\end{abstract}

Kata kunci: model, permainan, aktivitas luar kelas, kognitif, afektif, psikomotorik

\section{THE OUTDOOR ACTIVITY GAME MODEL TO DEVELOP THE ASPECT OF COGNITIVE, AFFECTIVE, AND PSYCHOMOTOR OF THE SENIOR HIGH SCHOOL STUDENTS}

\begin{abstract}
This study aims at producing outdoor activity game models which are proper to be used for physicall education learning and developing cognitive, affective, and psychomotor domains for senior high school students. This educational research and development was carried out following the steps of developing research, consisting of: (1) collecting information, (2) information analysis, (3) developing initial product, (4) expert validation and revision, (5) preliminary field test and revision, (6) main field test and revision, and (7) making the final product. The small field try out is done for the students of the class X-H and XI-IPA 3 from SMA N 1 Prambanan, with the total number of students 66. The big field try out is done for the students of class X-G, X-H, XI-IPS, and XI Bahasa from SMA $N 1$ Prambanan, with the total number students 132. The data instruments collecting which were used were: (1) interview guide, (2) rating scale, (3) observation guide for games observation, (4) observation guide for games effectiveness, and (5) observation guide for perpetrator teachers, (6) scoring rubric for measuring student's work. The data were analyzed using quantitative descriptive analysis and qualitative descriptive analysis. The results of the study in the form of seven models of the game are proper and effective to be used in physicall education, this is proved by percentage result about $100 \%$ from score scale questioner data, game model observation, observation for the offender trial teacher. Besides, the game is also effective for developing the aspect of cognitive, affective, and psychomotor which is proved by the increasing of percentage average of the students about $21 \%$.
\end{abstract}

Keywords: models, games, outdoor activity, cognitive, affective, psychomotor 


\section{Jurnal Keolahragaan 3 (2), September 2015 - 165}

Hendra Setyawan, Dimyati

\section{PENDAHULUAN}

Masa remaja menjadi masa yang penting karena merupakan masa transisi yang memungkinkan timbulnya masa krisis yang biasanya ditandai dengan kecenderungan munculnya perilaku-perilaku yang menyimpang (Hurlock, 2006, p.76). Melihat kondisi kejiwaan yang rata-rata masih labil dan punya karakteristik yang berbeda-beda pada remaja menengah yang sekaligus juga berstatus sebagai peserta didik di bangku SMA, tidak mustahil apabila banyak para pelajar melakukan tindakan-tindakan kriminal yang diakibatkan dari interaksi terhadap lingkungan, pergaulan dan juga asupan pendidikan yang negatif.

Salah satu aktivitas yang bisa dilakukan untuk membentuk dan mengembangkan ranah afektif pada remaja SMA adalah dengan kegiatan olahraga dan permainan. Perkembangan dan terbentuknya karakter seseorang dipengaruhi oleh kemampuan kognisi dan daya tangkapnya dalam berinteraksi dengan lingkungan sosial budaya. Oleh karena itu, karakter seseorang terbentuk bukan saja karena menirukan melalui pengamatan, tetapi juga dapat diajarkan melalui situasi olahraga, latihan, dan aktivitas fisik (Weinberg dan Gould, 2003, p.533).

Menurut Mutohir (2002, p.15) olahraga adalah proses sistematik yang berupa segala kegiatan atau usaha yang dapat mendorong mengembangkan, dan membina potensi-potensi jasmaniah dan rohaniah seseorang dalam bentuk permainan, perlombaan atau pertandingan, dan kegiatan jasmani yang intensif untuk memperoleh rekreasi, kemenangan, dan prestasi puncak dalam rangka pembentukan manusia Indonesia seutuhnya. Lembaga pendidikan yang diselenggarakan pemerintah yang mencakup pendidikan jasmani olahraga kesehatan dan rekreasi, yang pada dasarnya merupakan bagian yang tidak terpisahkan dari sistem pendidikan secara keseluruhan diharapkan mampu mengaplikasikan domain kognitif, afektif dan psikomotorik, sehingga terbentuk peserta didik yang unggul dan berkarakter.

Aktivitas luar kelas yang merupakan bagian dari kurikulum pendidikan jasmani olahraga dan kesehatan di SMA menjadi solusi fenomena kejenuhan pengembangan pembelajaran di dalam ruang. Kegiatan aktivitas luar kelas dapat berupa permainan, cerita, olahraga, eksperimen, perlombaan, mengenal kasus-kasus lingkungan di sekitarnya, diskusi penggalian solusi, aksi lingkungan, dan jelajah lingkungan
(Putri, 2006, p.1). Praktik aktivitas luar kelas yang diisi dengan kegiatan permainan dapat mentransfer nilai-nilai kognitif, afektif, dan psikomotorik (Depdiknas, 2006, p.703).

Suparlan (2008, p.15) menyatakan bahwa "permainan outbound sendiri secara umum dapat juga diartikan sebagai kegiatan bersama di luar kelas, atau di luar ruangan." Kegiatan bersama di luar kelas yang berisi permainan outbound dapat digunakan untuk mewujudkan tujuan pendidikan. Menurut Arnold (2002, p.34), pada anak-anak dan remaja, aktivitas fisik yang dirancang dalam outbound didesain untuk mengembangkan berbagai aspek, yakni: (1) aspek organik, (2) aspek neuromuskuler, (3) aspek interpretatif, (4) aspek sosial, dan (5) aspek emosional.

Bermain mampu membawa anak dan remaja ke arah perubahan yang positif baik dalam aspek fisik, psikis, maupun sosial. Pendidikan luar kelas melalui aktivitas permainan di alam bebas dijadikan sebagai alternatif baru dalam pembentukan ranah afektif peserta didik. Ini terutama dalam pembentukan sikap atau karakter kerja sama, tanggung jawab, percaya diri, kejujuran, kedisiplinan, tolong-menolong, kerja keras, dan saling menghargai. Karakter atau sikap yang tercakup dalam ranah afektif tersebut selayaknya harus dimiliki oleh seorang individu manusia yang ideal.

Menyadari arti penting pelaksanaan kegiatan aktivitas luar kelas bagi siswa, peneliti melakukan kajian awal mengenai muatan kurikulum SMA, dan berasumsi bahwa terdapat permasalahan yang dihadapi guru dalam pelaksanaan pembelajaran aktivitas luar kelas. Berdasarkan hal tersebut peneliti melakukan wawancara sekilas dengan salah beberapa guru SMA dengan hasil bahwa memang terdapat permasalahan di lapangan terkait pembelajaran akitivitas luar kelas. Oleh karena itu, peneliti tertarik untuk melakukan penyelidikan lebih jauh.

Selanjutnya, dilakukan pengumpulan informasi lebih lanjut dengan melakukan studi pendahuluan baik dengan cara studi pustaka maupun wawancara langsung dengan para guru pendidikan jasmani SMA di lapangan. Hal yang dilakukan dalam studi pustaka yaitu mengumpulkan bahan mengenai teori-teori, data, dan hasil penelitian yang terkait dengan penelitian ini. Di sisi lain, wawancara dilakukan terhadap beberapa guru pendidikan jasmani SMA dari beberapa sekolah di Yogyakarta dan Jawa Tengah. 


\section{Jurnal Keolahragaan 3 (2), September 2015 - 166}

Hendra Setyawan, Dimyati

Permasalahan pertama yang muncul adalah materi aktivitas luar kelas belum bisa dijalankan dengan maksimal oleh guru pada saat proses pembelajaran pendidikan jasmani, khususnya di SMA. Permasalahan yang kedua adalah materi aktivitas luar kelas dianggap kurang penting untuk diutamakan dalam pembelajaran pendidikan jasmani. Permasalahan yang ketiga adalah maraknya kenakalan remaja yang juga berstatus sebagai pelajar SMA yang terjadi di Yogyakarta dan Jawa Tengah seperti di Sleman, dan Klaten, terutama yang berkaitan dengan pelanggaran terhadap tata tertib sekolah.

Oleh karena itu, peneliti ingin mengembangkan model-model permainan di alam bebas yang mengandung nilai-nilai sikap atau afektif, yang dapat digunakan guru penjas SMA sebagai salah satu bentuk pembelajaran. Selain itu model permainan juga berisi materi pelajaran lain yang terdapat dalam kurikulum, yaitu ranah kognitif dan psikomotor. Dengan demikian penelitian ini diarahkan dalam rangka mengembangkan model permainan aktivitas luar kelas yang mengembangkan nilai-nilai ranah kognitif, afektif, dan psikomotorik yang dapat digunakan sebagai pembelajaran pendidikan jasmani di SMA.

\section{Konsep Aktivitas Luar Kelas dan Outbound}

Pendidikan luar kelas merupakan aktivitas luar sekolah yang berisi kegiatan di luar kelas atau sekolah dan di alam bebas lainnya, seperti bermain di lingkungan sekolah, taman, perkampungan, nelayan, berkemah, dan kegiatan yang bersifat petualangan, serta pengembangan aspek pengetahuan yang relevan (Komaruddin, 2007, p.2). Pendidikan luar kelas merupakan salah satu ruang lingkup mata pelajaran pendidikan jasmani, olahraga, dan kesehatan di SMA. Pendidikan luar kelas bertujuan agar siswa dapat beradaptasi dengan lingkungan dan alam sekitar, mengetahui pentingnya keterampilan hidup, pengalaman hidup di lingkungan dan alam sekitar, dan memiliki apresiasi terhadap lingkungan dan alam sekitar.

Aktivitas luar kelas merupakan salah satu bentuk kegiatan bermain yang dilakukan di tempat terbuka tanpa harus terfokus pada ukuran lapangan. Bermain pada dasarnya adalah proses experiental learning yang pelakunya mengalami dan merasakan secara langsung. Hal ini berbeda dengan kegiatan belajar di ruang kelas yang lebih menonjolkan salah satu aspek, misalnya aspek kognitif. Kegiatan belajar yang efektif adalah dilakukan dengan belajar lang- sung, dengan siswa bisa merasakan dan mengalami langsung apa yang mereka pelajari. Dampak dan pengaruh yang ditimbulkan oleh proses ini akan mudah diserap, dipahami, dan diingat lebih lama dibanding jika hanya menggarap salah satu aspek (Supendi, 2008, p.11).

Outbound sendiri secara umum juga dapat diartikan sebagai kegiatan bersama di luar kelas, atau di luar ruangan (Suparlan, 2008, p.15). Dengan kata lain kegiatan outbound adalah kegiatan bersama di alam bebas atau terbuka. Kegiatan outbound merupakan rangkaian kegiatan yang dirancang sebagai kegiatan yang menyenangkan, karena di dalamnya terdapat konsep permainan yang bertujuan membangun berbagai unsur-unsur positif, di antaranya adalah ranah kognitif, afektif, dan psikomotorik. Outbound merupakan pelatihan manajemen diri (self management) yang memadukan olah pikir, rasa, dan raga yang biasa dilakukan di alam terbuka dan dikondisikan di luar kebiasaan sehingga dapat memberikan suasana baru yang menyenangkan bagi peserta yang mengikutinya (Ancok, 2002, p.30). Outbound adalah usaha olah diri (olah pikir dan fisik) yang sangat bermanfaat bagi peningkatan dan pengembangan motivasi, kinerja, dan prestasi dalam rangka melaksanakan tugas dan kepentingan organisasi secara lebih baik lagi (Kimpraswil, 2007, p.1).

Menurut Rocmah (2012, p.14) outbound adalah suatu program pembelajaran di alam terbuka yang berdasarkan pada prinsip experiential learning (belajar melalui pengalaman langsung) yang disajikan dalam bentuk permainan, simulasi, diskusi dan petualangan sebagai media penyampaian materi. Dengan konsep interaksi antaranak didik dan alam melalui kegiatan simulasi di alam terbuka. Hal tersebut diyakini dapat memberikan suasana yang kondusif untuk membentuk sikap, cara berpikir serta persepsi yang kreatif dan positif dari setiap siswa guna membentuk jiwa kepemimpinan, kebersamaan (teamwork), keterbukaan, toleransi dan kepekaan yang mendalam, yang pada harapannya akan mampu memberikan semangat, inisiatif, dan pola pemberdayaan baru dalam suatu sekolah. Outbound merupakan salah satu model pembelajaran yang tepat untuk pendidikan yang menggunakan alam sebagai medianya. Adapun bentuk kegiatannya berupa permainan yang memberikan tantangan, sehingga anak berupaya untuk terus berusaha menggali dan mengembangkan potensi-potensi yang dimilikinya. Outbound dapat juga dilakukan 
untuk menyampaikan materi-materi yang terdapat pada kurikulum pembelajaran nasional.

\section{Permainan ALK (Outbound) sebagai Pem- belajaran Penjas di SMA}

Menurut Ancok (2000, p.3) outbound adalah kegiatan di alam terbuka (outdoor), outbound juga dapat memacu semangat belajar. Outbound merupakan sarana penambah wawasan pengetahuan yang di dapat dari serangkaian pengalaman berpetualang sehingga dapat memacu semangat dan kreativitas seseorang. Bentuk kegiatan outbound berupa stimulasi kehidupan melalui permainan-permainan (games) yang kreatif, rekreatif, dan edukatif, baik secara individual maupun kelompok, dengan tujuan untuk pengembangan diri maupun kelompok. Outbound training adalah kegiatan pelatihan di luar ruangan atau di alam terbuka (outdoor) yang menyenangkan dan penuh tantangan. Bentuk kegiatannya berupa simulasi kehidupan melalui permainan (games) yang kreatif, rekreatif, dan edukatif, baik secara individual maupun kelompok, dengan tujuan untuk pengembangan diri (personal development). Melalui pelatihan outbound, diharapkan lahir individu manusia yang penuh motivasi, berani, percaya diri, berpikir kreatif, memiliki rasa kebersamaan, tanggung jawab, kooperatif, rasa saling percaya diri dan lain-lain (Asti, 2009, p.11).

Dalam kegiatan outbound, paradigma pembelajaran yang diterapkan adalah berpusat pada peserta, mengembangkan kreativitas peserta, kondisi menyenangkan, mengembangkan beragam kemampuan, menyediakan pengalaman belajar yang beragam, belajar melalui berbuat konstekstual, pendidikan adalah proses memanusiawikan manusia kembali, serta meliputi tiga kelompok belajar yaitu kesadaran magis, kesadaran naif, kesadaran kritis (Suyatno, 2006, p.2). Adapun prinsip outbound atau aktivitas luar kelas dan alam bebas, yakni alam digunakan sebagai sumber belajar. Di dalamnya terdapat simulasi kehidupan, memperoleh pengalaman baru, mendapatkan kegembiraan dan kesenangan, mendapatkan tantangan untuk mengaktualisasikan diri, mencoba sesuatu yang baru dengan bereksperimen, berintegrasi dengan kelompok, peserta sebagai subjek bukan objek, pendidik sebagai fasilitator/ pemandu kegiatan, dan kegiatan ini terpola atau terstruktur dengan baik.

Kegiatan outbound juga merupakan strategi belajar yang dilakukan di alam terbuka, penggunaannya dinilai memberikan kontribusi positif terhadap kesuksesan belajar (Ancok, 2006, p.2). Tujuan dari permainan outbound adalah untuk mengembangkan sikap keterbukaan dan keberanian diri sambil menikmati alam bagi individu. Kesempatan dan kebebasan untuk melakukan bermacam-macam kegiatan akan memberikan pengalaman baru bagi peserta. Selain itu, pengalaman berpartisipasi dalam kegiatan permainan outbound akan mengajarkan siswa untuk memaknai nilai-nilai positif adegan permainan tersebut, sehingga dapat diaplikasikan dalam kehidupan nyata. Hal ini dikarenakan kegiatan di dalam outbound banyak menggunakan aktivitas permainan secara kelompok dengan menggunakan sejumlah aturan tertentu yang mentransfer ranah kognitif, afektif, dan psikomotorik.

\section{Tujuan dan Manfaat Aktivitas Luar Kelas (Outbound)}

Aktivitas luar kelas merupakan salah satu bentuk kegiatan bermain yang dilakukan tempat terbuka tanpa harus terfokus pada ukuran lapangan. Bermain pada dasarnya adalah proses experiental learning, yang pelakunya mengalami dan merasakan secara langsung. Hal ini berbeda dengan kegiatan belajar di ruang kelas yang lebih menonjolkan salah satu aspek, misalnya aspek kognitif. Meskipun demikian, kegiatan belajar yang efektif adalah dilakukan dengan belajar langsung, dengan siswa bisa merasakan dan mengalami langsung apa yang pelajarinya. Dampak dan pengaruh yang ditimbulkan oleh proses ini akan mudah diserap, dipahami, dan diingat lebih lama dibanding jika hanya menggarap salah satu aspek (Supendi, 2008, p.11). Lebih lanjut Kurniawan (2012, p.4) menyatakan bahwa permainan aktivitas luar kelas dapat meningkatkan minat belajar siswa karena dalam permainan ini siswa dituntut untuk bergerak aktif, saling bekerja sama dan saling melakukan kekompakan tim agar dapat menyelesaikan berbagai tantangan setiap permainan.

Manfaat pendidikan luar kelas selain sebagai pengembang potensi diri dan motivasi, dapat juga sebagai pembentuk sikap atau karakter peserta didik yang baik. Megawangi (2007, pp.21-23) menjelaskan ada sembilan pilar karakter yang membentuk kepribadian yang cerdas, bermoral dan unggul karena keterlibatan dalam kegiatan luar kelas. Sembilan pilar itu adalah sebagai berikut: (1) cinta kepada Tuhan dan alam semesta beserta isinya, (2) menum- 
buhkan rasa tanggung jawab, kedisiplinan dan kemandirian, (3) kejujuran, (4) hormat dan santun, (5) kasih sayang, kepedulian dan kerja sama, (6) percaya diri, kreatif, kerja keras dan pantang menyerah, (7) keadilan dan kepemimpinan, (8) sikap baik dan rendah hati, dan (9) toleransi, cinta damai, dan persatuan.

Selain itu pendidikan luar kelas juga mengembangkan kreativitas, tanggung jawab, kerja sama, disiplin, kejujuran, tolong menolong, motivasi diri, kompetisi, problem solving dan kepercayaan diri. Oleh karenanya agar anak dan remaja memiliki kepribadian yang bagus perlu diciptakan lingkungan yang kondusif, sehingga pada masa pertumbuhan dan perkembangannya akan menjadi pribadi yang baik dan berkarakter. Ada tiga komponen yang membentuk sikap atau karakter anak dan remaja, yaitu: keluarga, sekolah dan komunitas, seperti komunitas sosial, fisik maupun lingkungan alam. Interaksi manusia dan lingkungan alam yang dekat akan melahirkan kedekatan dan penghayatan terhadap kenyataan hidup. Penghayatan inilah yang membentuk cara pandang serta penghayatan akan totalitas cara pandang mengenai hidup yang mencerminkan karakter anak (Goleman, 2000, p.35).

Bentuk-bentuk kegiatan aktivitas luar kelas yang lebih dikenal oleh sebagian besar masyarakat adalah kegiatan outbond. Kegiatan outbound biasanya diisi dengan permainan dan petualangan untuk mencapai tujuan-tujuan tertentu. Outbound sendiri adalah merupakan bagian dari pendidikan aktivitas luar kelas yang memiliki beberapa manfaat bagi para siswa atau peserta yang mengikutinya. Menurut Ancok (2002, pp.34-35) manfaat yang diperoleh dari kegiatan outbound di antaranya: (1) berpikir kreatif (creative thinking), (2) mempunyai hubungan interpersonal yang baik, (3) berkomunikasi secara efektif, (4) memotivasi diri dan orang lain, dan (5) mempunyai kemampuan dalam pengelolaan diri.

Tujuan utama kegiatan outbound menurut Arovah $(2010$, p.3) adalah menimbulkan karakter positif bagi peserta, baik bersifat personel maupun tim yang ditandai dengan meningkatnya beberapa hal yakni sebagai berikut: (1) komunikasi efektif (effective communication), (2) pengembangan tim (team building), (3) pemecahan masalah (problem solving), (4) kepercayaan diri (self confidence), (5) kepemimpinan (leadership), (6) kerja sama (synergi), (7) permainan yang menghibur dan menyenangkan (fun games), (8) konsentrasi/ fokus (concentration), dan (9) kejujuran/ sportivitas.

Manfaat tersebut bermuara pada tercapainya pengembangan diri (personal development) dan tim (team development) dalam berbagai aspek kognitif, afektif, dan psikomotorik yang secara langsung dapat dirasakan oleh para peserta. Hal ini penting mengingat perkembangan ranah kognitif, afektif, dan psikomotorik sangat berpengaruh terhadap kesuksesan seseorang dalam kehidupan yang dijalaninya. Para pakar di bidang kecerdasan emosi berpendapat bahwa sukses dalam karier di perusahaan (juga di ranah kehidupan lainnya) lebih ditentukan oleh kecerdasan emosional dibandingkan dengan kecerdasan intelektual. Oleh karena itu, upaya untuk mengembangkan kecerdasan emosional mendapat perhatian yang semakin besar (Ancok, 2002, p.28).

\section{Ranah Kognitif}

Perkembangan kognitif pada hakikatnya merupakan hasil dari proses asimilasi berkaitan dengan penyerapan informasi baru ke dalam informasi yang telah ada di dalam skema (struktur kognitif anak) (Mustamir dan Sudrajat, 2009, p.29). Menurut teori kognitif Piaget, anak beradaptasi dengan menginterpretasikan objek dan kejadian-kejadian di sekitarnya (Desmita, 2008, p.46). Vygotsky berpandangan bahwa budaya anak membentuk perkembangan kognitif anak dengan menentukan apa dan bagaimana anak belajar tentang dunia (Ramli, 2005, p.96).

Dimensi karakteristik perkembangan kognitif, antara lain sebagai berikut: (1) dapat memahami konsep makna yang berlawanan seperti kosong-penuh, ringan-berat, atas-bawah, dan sebagainya, (2) dapat memadankan bentuk geometri (lingkaran, persegi, dan segitiga) dengan objek nyata atau melalui visualisasi gambar, (3) dapat menumpuk balok atau gelang-gelang sesuai ukurannya secara berurutan, (4) dapat mengelompokkan benda yang memiliki persamaan warna, bentuk, dan ukuran, (5) dapat menyebutkan pasangan benda, mampu memahami sebab akibat, (6) dapat merangkai kegiatan sehari-hari dan menunjukkan kapan setiap kegiatan dilakukan, (7) menceritakan kembali tiga gagasan utama dari suatu cerita, (8) mengenali dan membaca tulisan melalui gambar yang sering dilihat di rumah atau di sekolah, (9) mengenali dan menyebutkan angka 1-10 (Depdiknas 2007, p.9). Kesimpulannya bahwa kognitif adalah suatu proses berpikir untuk memecahkan masalah atau mengambil 


\section{Jurnal Keolahragaan 3 (2), September 2015 - 169}

Hendra Setyawan, Dimyati

sebuah keputusan dari yang abstrak ke yang konkret dengan melihat keadaan lingkungan sekitar.

\section{Ranah Afektif}

Afektif berhubungan dengan emosi seperti perasaan, nilai, apresiasi, motivasi, dan sikap. Terdapat lima kategori utama afektif dari yang paling sederhana sampai kompleks yaitu penerimaan, tanggapan, penghargaan, pengorganisasian, dan karakterisasi berdasarkan nilainilai atau internalisasi nilai. Bloom dan Masia (Nasution, 2009, pp.71-73) menyatakan bahwa garis besar ranah afektif adalah sebagai berikut: (a) menerima (memperhatikan) menaruh perhatian, meliputi kesadaran, kerelaan untuk menerima, mengarahkan perhatian, (b) merespons, yakni memberikan reaksi terhadap suatu gejala (dan sebagainya) secara terbuka, melakukan sesuatu sebagai respons terhadap gejala itu, meliputi merespons secara diam-diam, bersedia merespons, merasa kepuasan dalam merespons, mengalami kegembiraan dalam reaksinya terhadap suatu gejala, (c) menghargai, yakni memberi penilaian atau kepercayaan kepada suatu gejala yang cukup konsisten, meliputi menerima suatu nilai, mengutamakan suatu nilai, komitmen terhadap suatu nilai, (d) organisasi, yakni mengembangkan nilai-nilai sebagai suatu sistem, termasuk hubungan antar-nilai dan tingkat prioritas nilai-nilai itu, meliputi mengonseptualisasi nilai, dan mengorganisasi suatu sistem nilai, (e) karakteristik suatu nilai atau perangkat nilai-nilai, yakni mengadakan sintesis dan internalisasi sistem nilai-nilai dengan cara yang cukup selaras dan mendalam sehingga individu bertindak konsisten dengan nilai-nilai, keyakinan atau cita-cita yang merupakan inti falsafah dan pandangan hidupnya, meliputi pedoman umum dan karakterisasi.

\section{Ranah Psikomotorik}

Menurut Harrow kemampuan psikomotorik melibatkan gerak adaptif (adaptive movement) atau gerak terlatih dan keterampilan komunikasi berkesinambungan (non-discursive communication) (Depdiknas, 2008, p.6). Menurut Nasution (2012, pp.72-73) ranah psikomotorik kurang mendapat perhatian para pendidik dibandingkan dengan kedua ranah lainnya. Akhir-akhir ini gerakan kesehatan dan kesegaran (fisik dan mental) kembali memusatkan perhatian kepada ranah psikomotorik ini. Keenam tingkatan berkisar antara gerak refleks sebagai tingkatan yang paling rendah sampai gerakan ekspresif dan interpretatif pada tingkat yang paling tinggi. Garis besar ranah psikomotorik ini adalah sebagai berikut: (a) gerak refleks, (b) gerak dasar yang fundamental yang meliputi: gerak lokomotor, gerak non-lokomotor, dan gerak manipulatif, (c) keterampilan perseptual meliputi: diskriminasi kinestetik, diskriminasi visual, diskriminasi auditoris, diskriminasi taktil, keterampilan perseptual yang terkoordinasi, (d) keterampilan fisik meliputi ketahanan, kekuatan, kelentukan, kelincahan, (e) gerakan terampil meliputi keterampilan adaptif yang sederhana, keterampilan adaptif gabungan, keterampilan adaptif yang kompleks, (f) komunikasi non-diskursif (hubungan tanpa bahasa, melainkan melalui gerakan), meliputi gerak ekspresif, gerak interpretatif.

\section{Karakteristik Remaja SMA}

Tugas-tugas perkembangan pada masa remaja menurut Wong (2008, pp.45-50) antara lain sebagai berikut: (1) mencapai hubungan baru dan yang lebih matang dengan teman sebaya baik pria maupun wanita, (2) mencapai peran sosial pria dan wanita, (3) menerima keadaan fisiknya dan menggunakan tubuhnya secara efektif, (4) mengharapkan dan mencapai perilaku sosial yang bertanggung jawab, (5) mencapai kemandirian emosional dari orang tua dan orang-orang dewasa lainnya, (6) mempersiapkan karier ekonomi, (7) mempersiapkan perkawinan dan keluarga, (8) memperoleh perangkat nilai dan sistem etis sebagai pegangan untuk berperilaku mengembangkan ideologi.

\section{METODE}

\section{Jenis Penelitian}

Penelitian ini merupakan penelitian pengembangan. Penelitian pengembangan yang dalam istilah asingnya educational research and development $(\mathrm{R} \& \mathrm{D})$ adalah proses yang digunakan untuk mengembangkan dan memvalidasi produk-produk pendidikan, baik produk yang berupa objek material seperti buku teks, film pengajaran, dan sebagainya maupun produk yang berupa proses dan prosedur yang ditemukan seperti metode mengajar atau metode mengorganisasikan pengajaran (Borg \& Gall, 1983, p.772). Penelitian research and develop-ment ( $\mathrm{R} \& \mathrm{D})$ yaitu metode penelitian yang digunakan untuk menghasilkan produk tertentu dan menguji keefektifan produk tersebut (Sugiyono, 2009, p.407). 
Adapun pengembangan yang dilakukan dalam penelitian ini yaitu untuk menghasilkan model-model permainan aktivitas luar kelas bagi siswa SMA yang mengembangkan ranah kognitif, afektif, dan psikomotorik yang layak digunakan. Pengembangan dilakukan berdasarkan kajian terhadap muatan kurikulum SMA dan literatur. Pemilihan bentuk-bentuk aktivitas permainan berdasar pada tahap-tahap perkembangan dan karakteristik siswa, sehingga model yang dihasilkan diharapkan sesuai bagi siswa.

\section{Prosedur Penelitian dan Pengembangan}

Prosedur pengembangan dalam penelitian ini sejalan dengan langkah-langkah penelitian pengembangan menurut Borg \& Gall (1983, p.775) yang mengemukakan bahwa dalam melakukan penelitian pengembangan terdapat 10 langkah yang harus ditempuh, yaitu: (1) pengumpulan hasil riset dan informasi, (2) perencanaan, (3) mengembangkan produk awal, (4) uji coba awal, (5) revisi untuk menyusun produk utama, (6) uji coba lapangan utama, (7) revisi untuk menyusun produk operasional, (8) uji coba produk operasional, (9) revisi produk final, dan (10) diseminasi dan implementasi produk hasil pengembangan.

Berdasarkan penjelasan tersebut, langkah-langkah prosedur penelitian dan pengembangan yang dilakukan dalam penelitian ini kemudian diadaptasi menjadi tujuh rancangan prosedur penelitian pengembangan sebagai berikut.

Pengumpulan Informasi di Lapangan

Peneliti melakukan kajian awal mengenai muatan kurikulum SMA, dan berasumsi bahwa terdapat permasalahan yang dihadapi guru SMA dalam pelaksanaan pembelajaran aktivitas luar kelas. Berdasarkan hal tersebut peneliti melakukan wawancara sekilas dengan salah satu guru SMA dengan hasil bahwa memang terdapat permasalahan di lapangan terkait pembelajaran akitivitas luar kelas. Oleh karena itu, peneliti tertarik untuk melakukan penyelidikan lebih jauh.

Proses selanjutnya, dilakukan pengumpulan informasi lebih lanjut dengan melakukan studi pendahuluan baik dengan cara studi pustaka maupun wawancara langsung dengan para guru SMA di lapangan. Hal yang dilakukan dalam studi pustaka yaitu mengumpulkan bahan mengenai teori-teori, data, dan hasil penelitian yang terkait dengan penelitian ini. Wawancara dilakukan terhadap beberapa guru pendidikan jasmani SMA dari beberapa sekolah di Yogyakarta dan Jawa Tengah (Kodya, Gunungkidul, dan Klaten) untuk menyelidiki permasalahanpermasalahan yang ditemui dalam pelaksanaan pembelajaran pendidikan jasmani di SMA, terutama dalam pembelajaran materi aktivitas luar kelas.

\section{Melakukan Analisis terhadap Informasi yang telah Dikumpulkan}

Analisis dilakukan terhadap data hasil studi pustaka dan wawancara. Analisis terhadap hasil studi pustaka digunakan untuk pemantapan dalam memfokuskan masalah yang dikaji. Sementara analisis terhadap hasil wawancara dilakukan untuk mengetahui kebenaran asumsi peneliti dari kondisi nyata di lapangan mengenai permasalahan yang ada. Selanjutnya, disimpulkan mengenai permasalahan-permasalahan yang dihadapi guru SMA dalam pembelajaran aktivitas luar kelas di lapangan.

\section{Mengembangkan Produk Awal}

Setelah proses analisis, peneliti mulai memformulasikan suatu produk guna membantu guru SMA mengatasi permasalahan yang ditemui dalam pelaksanaan pembelajaran aktivitas luar kelas. Produk ini masih berupa produk awal dan dalam pengembangannya dilakukan hal-hal sebagai berikut: (1) menganalisis muatan kognitif, afektif, dan psikomotorik yang terkandung dalam kurikulum SMA agar produk yang dirancang tidak melenceng dari panduan kurikulum yang ada, (2) menganalisis nilai-nilai sikap yang bisa dikembangkan melalui aktivitas permainan yang sesuai pertumbuhan dan perkembangan siswa SMA, (3) menganalisis karakteristik siswa SMA, (4) menganalisis tujuan pengembangan permainan aktivitas luar kelas, (5) mengembangkan model permainan aktivitas luar kelas yang mentransfer atau mengembangkan nilai-nilai kognitif, afektif, dan psikomotorik yang sesuai dengan kurikulum SMA.

\section{Validasi Ahli dan Revisi}

Sebelum dilakukan uji coba skala kecil terhadap produk awal, produk harus mendapat validasi dari para ahli materi, yaitu: (1) pakar pendidikan jasmani SMA, (2) pakar permainan anak usia dini dan remaja, dan (3) pakar pendidikan anak usia dini dan remaja. Pakar pendidikan jasmani anak usia dini dan remaja yang dipilih yaitu Pamuji Sukoco dari FIK UNY, sedangkan pakar permainan anak usia dini dan remaja yaitu Suharjana dari FIK UNY. Selan- 
jutnya, pakar pendidikan jasmani SMA yang berjumlah dua orang guru yaitu Achintia dan Ari Kurniawan selaku guru penjas SMA Negeri I Prambanan Klaten.

Pada proses validasi, para ahli materi menilai dan memberi masukan terhadap produk awal. Berdasarkan hal tersebut, dilakukan revisi terhadap produk awal. Proses revisi ini terus dilakukan sampai produk awal mencapai batas nilai tertentu yang telah ditetapkan, yang menunjukkan bahwa produk awal tersebut valid dan layak diujicobakan.

\section{Uji Coba Lapangan Skala Kecil dan Revisi}

Uji coba lapangan skala kecil dilakukan dan didokumentasikan dalam bentuk Video Compact Disc (VCD), yang kemudian diobservasi oleh para ahli materi. Observasi dilakukan terhadap substansi permainan, keefektifan model permainan, guru pelaksana uji coba, maupun draf produk buku, dan CD panduan permainan, dengan menggunakan pedoman observasi yang disusun oleh peneliti. Masukan yang diterima dari para pakar dan guru SMA ditindaklanjuti dengan melakukan revisi produk. Selain itu, masukan dari guru SMA pelaku uji coba juga dipertimbangkan sebagai bahan untuk merevisi produk.

\section{Uji Coba Lapangan Skala Besar dan Revisi}

Proses yang dilakukan pada tahap uji coba lapangan skala besar serupa dengan proses yang dilakukan pada tahap uji coba skala kecil. Hal yang membedakan terletak pada jumlah subjek uji coba skala besar yang lebih banyak daripada uji coba skala kecil. Dalam hal ini, subjek uji coba yang sudah mengikuti uji coba skala kecil tidak turut serta dalam uji coba skala besar. Proses revisi produk dilakukan setelah mendapat masukan dari para ahli materi untuk menghasilkan produk final. Masukan dari guru SMA tempat pelaksanaan uji coba skala besar juga dipertimbangkan sebagai bahan untuk merevisi produk.

Pada tahap uji coba skala besar ini juga dilakukan proses pengujian produk model permainan ALK apakah benar-benar berkontribusi meningkatkan ranah kognitif, afektif, dan psikomotorik siswa SMA. Uji efektivitas dilakukan dengan cara membandingkan hasil penilaian pada pertemuan tahap I (awal) dan pada pertemuan tahap II (akhir) pada subjek coba (siswa) yang sama.

Pada penerapan permainan pertemuan/ tahap I (awal) ahli materi (guru) memberikan penilaian terhadap siswa dengan pedoman rubrik penilaian. Selanjutnya, pada penerapan permainan pertemuan/tahap II (akhir) siswa diberikan perlakuan permainan yang sama seperti pada permainan tahap awal namun dilaksanakan pada waktu yang berbeda, dan selanjutnya diambil data penilaian akhir. Setelah data pada pertemuan/tahap I (awal) dan pertemuan/tahap II (akhir) diperoleh, langkah selanjutnya adalah membandingkan selisih ratarata antara data awal dan akhir.

\section{Pembuatan Produk Final}

Setelah melalui berbagai proses revisi dan juga uji efektivitas produk yang dikembangkan, selanjutnya dilakukan penyusunan dan pembuatan produk akhir berupa buku dan $\mathrm{CD}$ panduan permainan aktivitas luar kelas.

\section{Desain Uji Coba}

Uji coba dilakukan dengan tujuan untuk menyempurnakan model permainan dengan mempraktikkannya secara langsung di lapangan. Dalam penelitian ini, uji coba produk/draf model dilakukan sebanyak tiga kali, yaitu uji coba skala kecil, uji coba skala besar tahap I, dan uji coba skala besar tahap II. Uji coba produk skala kecil, uji coba skala besar tahap I, dan II dilakukan terhadap siswa SMA I Prambanan Klaten.

\section{Subjek Coba}

Subjek coba pada penelitian ini yaitu siswa kelas X dan XI dari SMAN I Prambanan Klaten. Uji coba skala kecil dilakukan terhadap siswa X-D dan XI-IPA 4 dari SMAN I Prambanan yang berjumlah 66 siswa. Sementara uji coba skala besar dilakukan terhadap siswa kelas X-G, X-H, XI-IPS 3, dan XI-BHS dari SMAN I Prambanan yang berjumlah 132 siswa. Untuk uji efektivitas dilakukan terhadap 32 siswa dari perwakilan kelas X dan XI.

\section{Jenis Data}

Jenis data yang diperoleh dalam penelitian dan pengembangan ini yaitu data kualitatif dan data kuantitatif. Data kualitatif berasal dari: (a) hasil wawancara dengan guru SMA, (b) data kekurangan model permainan dari ahli materi dan guru pelaku uji coba, dan (c) data masukan ahli materi dan guru pelaku uji coba terhadap model permainan. Data kuantitatif diperoleh dari: (a) penilaian ahli materi terhadap model permainan, (b) penilaian ahli materi terhadap keefektifan permainan, (c) 
penilaian ahli materi terhadap guru pelaku uji coba, dan (d) data hasil rubrik penilaian dan ketercapaian indikator tiap permainan yang didapatkan dari penilaian ahli materi (guru) pada uji efektivitas tahap awal dan akhir.

\section{Instrumen Pengumpulan Data}

Teknik pengumpulan data pertama yang digunakan yaitu teknik komunikasi langsung dengan menggunakan instrumen wawancara sebagai alat pengumpul data. Untuk melakukan kegiatan perekaman hasil wawancara digunakan alat perekam suara. Pertanyaan yang disusun dalam pedoman wawancara disesuaikan dengan tujuan pelaksanaan wawancara yaitu untuk menggali proses pembelajaran di SMA dan masalah-masalah yang dihadapi guru terkait pembelajaran aktivitas luar kelas, untuk mendukung latar belakang masalah penelitian.

Instrumen pengumpul data yang kedua yaitu menggunakan skala nilai. Skala nilai ini digunakan untuk memberikan penilaian terhadap model permainan yang dikembangkan sebelum pelaksanaan uji coba skala kecil. Setelah para ahli menilai bahwa model permainan sudah sesuai dengan unsur-unsur dalam skala nilai, model permainan baru dapat diujicobakan pada uji coba skala kecil.

Teknik pengumpulan data ketiga yang digunakan yaitu teknik observasi tidak langsung dengan instrumen observasi berupa daftar cek (check list) dan peralatan mekanik. Teknik observasi tidak langsung merupakan cara mengumpulkan data yang dilakukan melalui pengamatan dan pencatatan gejala-gejala yang tampak pada objek penelitian yang dilaksanakan setelah peristiwa atau situasi atau keadaannya terjadi (Nawawi \& Hadari, 2006, pp.67$68)$.

Instrumen pengumpulan data keempat yang digunakan adalah dengan instrumen penilaian siswa (rubrik penilaian) yaitu format penilaian yang digunakan guru untuk menilai kinerja siswa saat melaksanakan permainanpermainan yang dikembangkan. Format penilaian ini akan memudahkan guru dalam mengevaluasi penampilan siswa dan ketercapaian indikator yang diharapkan dari tiap permainan.

\section{Teknik Analisis Data}

Teknik analisis data yang dilakukan dalam penelitian ini yaitu analisis deskriptif kuantitatif dan analisis deskriptif kualitatif. Pada tahap pengembangan produk analisis deskriptif kuantitatif dilakukan untuk meng- analisis data-data berikut: (1) data skala nilai hasil penilaian para ahli materi terhadap draf model permainan sebelum pelaksanaan uji coba di lapangan, (2) data hasil observasi para ahli materi terhadap model permainan, (3) data hasil observasi para ahli materi terhadap keefektifan permainan, dan (4) hasil observasi para ahli materi terhadap guru pelaku uji coba (5) data hasil rubrik penilaian untuk mengukur kinerja siswa dan ketercapaian indikator dari tiap permainan. Sementara analisis deskriptif kualitatif dilakukan terhadap: (1) data hasil wawancara dengan guru SMA saat studi pendahuluan, (2) data kekurangan dan masukan terhadap model permainan baik sebelum uji coba maupun setelah uji coba di lapangan.

Draf awal permainan dianggap layak untuk diujicobakan dalam skala kecil apabila para ahli materi telah memberikan validasi dan menyatakan bahwa semua item klasifikasi dalam skala nilai dinilai "sesuai" dengan cara memberikan tanda centang $(\sqrt{ })$ pada kolom sesuai. Dalam hal ini terdapat dua jenis nilai, yaitu hasil penilaian "sesuai" mendapat nilai satu (1) dan hasil penilaian "tidak sesuai" mendapat nilai nol (0). Jika terdapat ahli materi yang berpendapat bahwa item klasifikasi tidak sesuai (nilai nol), dilakukan pengkajian ulang terhadap model permainan yang dapat ditindaklanjuti dengan proses revisi.

Untuk data hasil observasi para ahli materi terhadap model permainan, keefektifan model permainan, dan guru pelaku uji coba terdapat dua jenis nilai. Hasil observasi "ya" mendapat nilai satu (1) dan hasil observasi "tidak" mendapat nilai nol (0). Hasil penilaian terhadap item-item observasi dijumlahkan, lalu total nilainya dikonversikan untuk mengetahui kategorinya. Pengonversian nilai dilakukan dengan mengikuti standar penilaian acuan patokan (PAP). Dalam menginterpretasikan skor mentah menjadi nilai menggunakan pendekatan PAP, yang akan dipaparkan berikut ini (Nurhasan, 2001, p.282).

Tabel 1. Pedoman Konversi Nilai

\begin{tabular}{ccc}
\hline Skor Nilai & Kategori & Keterangan \\
\hline $80 \%-100 \%$ & A & Sangat Baik/Efektif \\
$70 \%-79 \%$ & B & Baik/Efektif \\
$60 \%-69 \%$ & C & Cukup Baik/Efektif \\
$45 \%-59 \%$ & D & Kurang Baik/Efektif \\
$<44 \%$ E & E & Sangat Kurang Baik/Efektif \\
\hline
\end{tabular}

Adapun pada tahapan proses untuk menguji keefektifan model permainan aktivitas 
luar kelas untuk meningkatkan ranah kognitif, afektif, dan psikomotorik bagi siswa SMA, analisis deskriptif kuantitatif dilakukan dengan menggunakan uji beda selisih peningkatan ratarata antara data hasil pertemuan tahap I (awal) dan pertemuan tahap II (akhir). Hal ini senada dengan pendapat Sugiyono (2009, p.346) bahwa "uji beda dilakukan untuk menguji perubahan yang terjadi akibat suatu perlakuan peneliti terhadap subjek penelitian dan membandingkan skor awal dan skor akhir." Peningkatan ranah kognitif, afektif, dan psikomotorik siswa dapat dilihat dari hasil penilaian berupa perbandingan antara hasil nilai pada penerapan permainan tahap I (awal) dan hasil nilai pada penerapan permainan tahap II (akhir). Untuk menganalisis data tersebut digunakan teknik uji efektivitas penelitian dengan menggunakan ketentuan skor kriterium/ideal (Sugiyono, 2013, p.305).

\section{HASIL DAN PEMBAHASAN}

Model permainan aktivitas luar kelas yang dikembangkan terdiri atas tujuh permainan, yaitu: (1) permainan perang terbuka, (2) permainan pesan berantai, (3) permainan gelas bocor, (4) permainan keseimbangan membawa air, (5) permainan lari jembatan, (6) permainan pipa air mengalir, dan (7) permainan rintangan menuang air.

\section{Skala Kecil}

\section{Permainan Perang Terbuka}

Berdasarkan data hasil observasi yang dilakukan oleh para ahli materi yang terdiri atas pakar pendidikan jasmani SMA (guru), pakar permainan anak usia dini dan remaja, dan pakar pendidikan jasmani anak usia dini dan remaja terhadap model permainan, keefektifan model permainan, dan guru pelaku uji coba telah menunjukkan perolehan nilai sebesar $100 \%$ dan masuk pada rentang skor nilai $80 \%$ s.d. $100 \%$, sehingga termasuk dalam kategori $\mathrm{A}=$ sangat baik/efektif.

\section{Permainan Pesan Berantai}

Berdasarkan data hasil observasi yang dilakukan oleh para ahli materi yang terdiri atas pakar pendidikan jasmani SMA (guru), pakar permainan anak usia dini dan remaja, dan pakar pendidikan jasmani anak usia dini dan remaja terhadap model permainan, keefektifan model permainan, dan guru pelaku uji coba telah menunjukkan perolehan nilai sebesar $100 \%$ dan masuk pada rentang skor nilai $80 \%$ s.d. $100 \%$, sehingga termasuk dalam kategori $\mathrm{A}=$ sangat baik/efektif.

\section{Permainan Gelas Bocor}

Berdasarkan data hasil observasi yang dilakukan oleh para ahli materi yang terdiri atas pakar pendidikan jasmani SMA (guru), pakar permainan anak usia dini dan remaja, dan pakar pendidikan jasmani anak usia dini dan remaja terhadap model permainan, keefektifan model permainan, dan guru pelaku uji coba telah menunjukkan perolehan nilai sebesar $100 \%$ dan masuk pada rentang skor nilai $80 \%$ s.d. $100 \%$, sehingga termasuk dalam kategori $\mathrm{A}=$ sangat baik/efektif.

\section{Permainan Keseimbangan Membawa Air}

Berdasarkan data hasil observasi yang dilakukan oleh para ahli materi yang terdiri atas pakar pendidikan jasmani SMA (guru), pakar permainan anak usia dini dan remaja, dan pakar pendidikan jasmani anak usia dini dan remaja terhadap model permainan, keefektifan model permainan, dan guru pelaku uji coba telah menunjukkan perolehan nilai sebesar $100 \%$ dan masuk pada rentang skor nilai $80 \%$ s.d. $100 \%$, sehingga termasuk dalam kategori $\mathrm{A}=$ sangat baik/efektif.

\section{Permainan Lari Jembatan}

Berdasarkan data hasil observasi yang dilakukan oleh para ahli materi yang terdiri atas pakar pendidikan jasmani SMA (guru), pakar permainan anak usia dini dan remaja, dan pakar pendidikan jasmani anak usia dini dan remaja terhadap model permainan, keefektifan model permainan, dan guru pelaku uji coba telah menunjukkan perolehan nilai sebesar $100 \%$ dan masuk pada rentang skor nilai $80 \%$ s.d. $100 \%$, sehingga termasuk dalam kategori $\mathrm{A}=$ sangat baik/efektif.

\section{Permainan Pipa Air Mengalir}

Berdasarkan data hasil observasi yang dilakukan oleh para ahli materi yang terdiri atas pakar pendidikan jasmani SMA (guru), pakar permainan anak usia dini dan remaja, dan pakar pendidikan jasmani anak usia dini dan remaja terhadap model permainan, keefektifan model permainan, dan guru pelaku uji coba telah menunjukkan perolehan nilai sebesar $100 \%$ dan masuk pada rentang skor nilai $80 \%$ s.d. $100 \%$, sehingga termasuk dalam kategori $\mathrm{A}=$ sangat baik/efektif. 


\section{Jurnal Keolahragaan 3 (2), September 2015 - 174}

Hendra Setyawan, Dimyati

Permainan Rintangan Menuang Air

Berdasarkan data hasil observasi yang dilakukan oleh para ahli materi yang terdiri atas pakar pendidikan jasmani SMA (guru), pakar permainan anak usia dini dan remaja, dan pakar pendidikan jasmani anak usia dini dan remaja terhadap model permainan, keefektifan model permainan, dan guru pelaku uji coba telah menunjukkan perolehan nilai sebesar $100 \%$ dan masuk pada rentang skor nilai $80 \%$ s.d. $100 \%$, sehingga termasuk dalam kategori $\mathrm{A}=$ sangat baik/efektif.

\section{Skala Besar}

\section{Permainan Perang Terbuka}

Berdasarkan data hasil observasi yang dilakukan oleh para ahli materi yang terdiri atas pakar pendidikan jasmani SMA (guru), pakar permainan anak usia dini dan remaja, dan pakar pendidikan jasmani anak usia dini dan remaja terhadap model permainan, keefektifan model permainan, dan guru pelaku uji coba telah menunjukkan perolehan nilai sebesar $100 \%$ dan masuk pada rentang skor nilai $80 \%$ s.d. $100 \%$, sehingga termasuk dalam kategori $\mathrm{A}=$ sangat baik/efektif.

\section{Permainan Pesan Berantai}

Berdasarkan data hasil observasi yang dilakukan oleh para ahli materi yang terdiri atas pakar pendidikan jasmani SMA (guru), pakar permainan anak usia dini dan remaja, dan pakar pendidikan jasmani anak usia dini dan remaja terhadap model permainan, keefektifan model permainan, dan guru pelaku uji coba telah menunjukkan perolehan nilai sebesar $100 \%$ dan masuk pada rentang skor nilai $80 \%$ s.d. $100 \%$, sehingga termasuk dalam kategori $\mathrm{A}=$ sangat baik/efektif.

\section{Permainan Gelas Bocor}

Berdasarkan data hasil observasi yang dilakukan oleh para ahli materi yang terdiri atas pakar pendidikan jasmani SMA (guru), pakar permainan anak usia dini dan remaja, dan pakar pendidikan jasmani anak usia dini dan remaja terhadap model permainan, keefektifan model permainan, dan guru pelaku uji coba telah menunjukkan perolehan nilai sebesar $100 \%$ dan masuk pada rentang skor nilai $80 \%$ s.d. $100 \%$, sehingga termasuk dalam kategori $\mathrm{A}=$ sangat baik/efektif.

\section{Permainan Keseimbangan Membawa Air}

Berdasarkan data hasil observasi yang dilakukan oleh para ahli materi yang terdiri atas pakar pendidikan jasmani SMA (guru), pakar permainan anak usia dini dan remaja, dan pakar pendidikan jasmani anak usia dini dan remaja terhadap model permainan, keefektifan model permainan, dan guru pelaku uji coba telah menunjukkan perolehan nilai sebesar $100 \%$ dan masuk pada rentang skor nilai $80 \%$ s.d. $100 \%$, sehingga termasuk dalam kategori $\mathrm{A}=$ sangat baik/efektif.

Permainan Lari Jembatan

Berdasarkan data hasil observasi yang dilakukan oleh para ahli materi yang terdiri atas pakar pendidikan jasmani SMA (guru), pakar permainan anak usia dini dan remaja, dan pakar pendidikan jasmani anak usia dini dan remaja terhadap model permainan, keefektifan model permainan, dan guru pelaku uji coba telah menunjukkan perolehan nilai sebesar $100 \%$ dan masuk pada rentang skor nilai $80 \%$ s.d. $100 \%$, sehingga termasuk dalam kategori $\mathrm{A}=$ sangat baik/efektif.

\section{Permainan Pipa Air Mengalir}

Berdasarkan data hasil observasi yang dilakukan oleh para ahli materi yang terdiri atas pakar pendidikan jasmani SMA (guru), pakar permainan anak usia dini dan remaja, dan pakar pendidikan jasmani anak usia dini dan remaja terhadap model permainan, keefektifan model permainan, dan guru pelaku uji coba telah menunjukkan perolehan nilai sebesar $100 \%$ dan masuk pada rentang skor nilai $80 \%$ s.d. $100 \%$, sehingga termasuk dalam kategori $\mathrm{A}=$ sangat baik/efektif.

\section{Permainan Rintangan Menuang Air}

Berdasarkan data hasil observasi yang dilakukan oleh para ahli materi yang terdiri atas pakar pendidikan jasmani SMA (guru), pakar permainan anak usia dini dan remaja, dan pakar pendidikan jasmani anak usia dini dan remaja terhadap model permainan, keefektifan model permainan, dan guru pelaku uji coba telah menunjukkan perolehan nilai sebesar $100 \%$ dan masuk pada rentang skor nilai $80 \%$ s.d. $100 \%$, sehingga termasuk dalam kategori $\mathrm{A}=$ sangat baik/efektif.

\section{Data Uji Efektivitas Produk}

Pada tahap uji coba skala besar ini juga dilakukan proses pengujian produk model 
permainan ALK apakah benar-benar berkontribusi meningkatkan ranah kognitif, afektif, dan psikomotor siswa SMA. Uji efektivitas dilakukan dengan cara membandingkan hasil penilaian pada pertemuan tahap I (awal) dan pada pertemuan tahap II (akhir) pada subjek coba (siswa) yang sama. Siswa yang menjadi sampel pada uji efektivitas model permainan aktivitas luar kelas untuk meningkatkan ranah kognitif, afektif, dan psikomotor dalam penelitian ini adalah siswa putra dan putri kelas X dan XI dari SMA N I Prambanan Klaten yang berjumlah 32 orang.

Proses penerapan model permainan pada pertemuan/tahap I (awal) ahli materi (guru) memberikan penilaian terhadap siswa dengan pedoman rubrik penilaian. Selanjutnya pada penerapan model permainan pertemuan/tahap II (akhir) siswa diberikan perlakuan permainan yang sama seperti pada permainan tahap awal namun dilaksanakan pada waktu yang berbeda, dan selanjutnya diambil data penilaian akhir. Setelah data pada pertemuan/tahap I (awal) dan pertemuan/tahap II (akhir) diperoleh, maka langkah selanjutnya adalah membandingkan selisih rata-rata antara data awal dan akhir.

Hasil penilaian dengan pedoman rubrik penilaian tersebut disajikan dalam bentuk data kuantitatif yang berbentuk persentase nilai ratarata. Data tersebut meliputi data hasil nilai yang diperoleh dari perhitungan dengan pedoman rubrik penilaian pada pertemuan tahap I (awal), data hasil nilai yang diperoleh dari perhitungan dengan pedoman rubrik penilaian pada pertemuan tahap II (akhir), dan persentase selisih data hasil peningkatan nilai rata-rata siswa antara pertemuan I (awal) dan II (akhir), yang dijelaskan pada tabel 2 berikut ini:

Tabel 2. Persentase Hasil Nilai Rata-rata Siswa pada Pertemuan Awal

\begin{tabular}{ccc}
\hline No & Permainan & Pertemuan Awal \\
\hline 1 & P. 1 & $76,9 \%$ \\
2 & P. 2 & $80,1 \%$ \\
3 & P. 3 & $78,9 \%$ \\
4 & P. 4 & $72,9 \%$ \\
5 & P. 5 & $70,0 \%$ \\
6 & P. 6 & $70,5 \%$ \\
7 & P. 7 & $73,3 \%$ \\
Persentase Nilai Keseluruhan & $522,6: 7=74,6 \%$ \\
\multicolumn{2}{c}{ Permainan Awal }
\end{tabular}

Tabel 3. Persentase Hasil Nilai Rata-rata Siswa pada Pertemuan Akhir

\begin{tabular}{lcr}
\hline No & Permainan & $\begin{array}{c}\text { Pertemuan } \\
\text { Awal }\end{array}$ \\
\hline 1 & P. 1 & $96,2 \%$ \\
2 & P. 2 & $97,3 \%$ \\
3 & P. 3 & $96,1 \%$ \\
4 & P. 4 & $94,8 \%$ \\
5 & P. 5 & $94,6 \%$ \\
6 & P. 6 & $94,8 \%$ \\
7 & P. 7 & $95,4 \%$ \\
Persentase Nilai Keseluruhan & $669,2: 7=$ \\
\multicolumn{2}{c}{ Permainan Akhir } \\
\hline
\end{tabular}

Tabel 4. Hasil Peningkatan Nilai Siswa antara

Pertemuan Awal dan Pertemuan Akhir

\begin{tabular}{|c|c|c|c|c|}
\hline No & Perm. & \multicolumn{2}{|c|}{ Pert. Awal Pert. Akhir } & Pngktn \\
\hline 1 & P. 1 & $76,9 \%$ & $96,2 \%$ & $19,3 \%$ \\
\hline 2 & P. 2 & $80,1 \%$ & $97,3 \%$ & $17,2 \%$ \\
\hline 3 & P. 3 & $78,9 \%$ & $96,1 \%$ & $17,2 \%$ \\
\hline 4 & P. 4 & $72,9 \%$ & $94,8 \%$ & $21,9 \%$ \\
\hline 5 & P. 5 & $70,0 \%$ & $94,6 \%$ & $24,6 \%$ \\
\hline 6 & P. 6 & $70,5 \%$ & $94,8 \%$ & $24,3 \%$ \\
\hline 7 & P.6 & $73,3 \%$ & $95,4 \%$ & $22,1 \%$ \\
\hline $\begin{array}{r}\mathrm{P} \\
\text { Penin } \\
\text { pada } \\
\text { Awa }\end{array}$ & $\begin{array}{l}\text { entase } \\
\text { ertemuan Nilai } \\
\text { lan Akhir }\end{array}$ & $\begin{aligned} & \frac{522,6}{7} \\
= & 74,6 \%\end{aligned}$ & $\begin{aligned} & \frac{669,2}{7} \\
= & 95,6 \%\end{aligned}$ & $\begin{array}{c}95,6-74,6 \\
=21 \%\end{array}$ \\
\hline
\end{tabular}

Dari proses uji efektivitas keseluruhan model permainan untuk meningkatkan ranah kognitif, afektif, dan psikomotor siswa SMA telah diperoleh data total nilai rata-rata siswa pada pertemuan awal sebesar $74,6 \%$ dan pertemuan akhir sebesar 95,6\%, sehingga telah terjadi perubahan/peningkatan nilai rata-rata siswa sebesar $21 \%$ yang diakibatkan dari penerapan model permainan. Dengan demikian bisa disimpulkan bahwa model permainan aktivitas luar kelas yang dikembangkan efektif untuk mengembangkan ranah kognitif, afektif, dan psikomotorik siswa SMA, hal ini dibuktikan dengan adanya perubahan atau peningkatan total nilai rerata siswa sebesar $21 \%$ pada keseluruhan permainan.

\section{SIMPULAN DAN SARAN}

\section{Simpulan tentang Produk}

Sebagaimana tujuan penelitian ini yaitu untuk menghasilkan model-model permainan aktivitas luar kelas bagi siswa SMA yang mengembangkan ranah kognitif, afektif, dan psikomotorik yang layak digunakan dalam pembelajaran pendidikan jasmani, dilakukan penelitian pengembangan dengan tujuh langkah, terdiri atas: (1) pengumpulan informasi di 
lapangan, (2) melakukan analisis terhadap informasi yang telah dikumpulkan, (3) mengembangkan produk awal (draf awal model), (4) validasi ahli dan revisi, (5) uji coba skala kecil dan revisi, (6) uji coba skala besar dan revisi, dan (7) pembuatan produk final.

Hasil penelitian menunjukan bahwa model permainan yang disusun layak dan efektif digunakan dalam pembelajaran penjas, hal ini ditunjukkan dengan perolehan persentase sebesar $100 \%$ dari data hasil kuesioner skala nilai, observasi model permainan, observasi keefektifan permainan, dan observasi guru pelaku uji coba. Selain itu model permainan juga efektif untuk mengembangkan ranah kognitif, afektif, dan psikomotorik, yang ditunjukkan dengan terjadinya peningkatan persentase nilai rata-rata siswa sebesar $21 \%$. Dengan demikian bisa disimpulkan bahwa model permainan aktivitas luar kelas yang dikembangkan layak digunakan dalam pembelajaran penjas, serta efektif dalam mengembangkan ranah kognitif, afektif dan psikomotorik bagi siswa SMA.

Produk dari penelitian pengembangan ini yaitu buku dan CD panduan permainan ALK yang mengembangkan ranah kognitif, afektif, dan psikomotorik bagi siswa SMA, yang berjudul "ALK Games". Buku dan CD panduan permainan ini berisi tujuh model permainan, yaitu: (1) permainan perang terbuka, (2) permainan pesan berantai, (3) permainan gelas bocor, (4) permainan keseimbangan membawa air, (5) permainan lari jembatan, (6) permainan pipa air mengalir, dan (7) permainan rintangan menuang air.

\section{Saran dan Pengembangan Lebih Lanjut}

Saran pemanfaatan berdasarkan penelitian pengembangan ini yaitu agar model permainan yang dikembangkan dapat digunakan guru sebagai salah satu bentuk pembelajaran pendidikan jasmani yang terintegrasi yang mengembangkan ranah kognitif, afektif, dan psikomotorik melalui aktivitas permainan di alam terbuka. Untuk dapat mewujudkan hal tersebut, perlu dilakukan sosialisasi kepada guru-guru pendidikan jasmani di SMA, SMK, dan MA, melalui seminar-seminar yang didukung oleh instansi pendidikan yang terkait.

Untuk pengembangan produk lebih lanjut agar peralatan pada produk ini menjadi lebih baik dan sempurna, dapat dilakukan pembakuan atau penyempurnaan peralatan-peralatan yang dipakai dalam produk ini, sehingga guru seba- gai pemakai produk dapat mengaplikasikan produk ini dengan praktis.

\section{DAFTAR PUSTAKA}

Ancok, Jamaludin. (2002). Outbound management training. Cetakan pertama edisi revisi. Yogyakarta: UII. Press.

Ancok, Jamaludin. (2006). Outbound management training. Yogyakarta: UII Press.

Arnold, M. E. (2002). Personal and life skill development through participation in the outbound program. Caring 5 (4.20): 0.81 .

Arovah, Novita Intan. (2010). Pelatihan outbond bagi guru penjaskes SMA seYogyakarta. Yogyakarta: FIK. UNY.

Asti, Badiatul Muchlisin. (2009). Fun outbound-merancang kegiatan outbound yang efektif. Yogyakarta: Diva Press.

Borg, Walter R., \& Gall, Meredith D. (1983). Educational research: An introduction, ( $4^{\text {th }}$ ed.) New York: Longman.

Depdiknas. (2006). Kurikulum tingkat satuan pendidikan. Jakarta: Depdiknas.

Depdiknas. (2007). Pedoman pembelajaran bidang pengembangan kognitif $T K$. Jakarta: Depdiknas.

Desmita. (2008). Psikologi perkembangan. Bandung: Rosda.

Goleman, D. (2000). Emotional intelligence. Jakarta: Gramedia Pustaka Utama.

Hurlock, E. (2006). Psikologi perkembangan suatu pendekatan sepanjang rentang kehidupan (edisi ke-4), alih bahasa Istiwidayanti dan Soedjarwo. Jakarta: Erlangga.

Kimpraswil. (2007). Outbound. http://www.kimpraswil.go.id/.Diakses: 01 Januari 2014.

Komarudin, Arief. (2007). Pendidikan jasmani olahraga dan kesehatan. http://pojokpenjas.blogspot.com/2007/1 2/babI-pendahuluan-rasional.htm. Diakses: 01 November 2013

Megawangi, R. (2007). Jangan remehkan pengasuhan otak anak. http://www.pendidikankarakter.edu. Diakses: November 2013. 
Mustamir, Pedak. (2009). Saatnya bersekolah. Yogjakarta: Buku Biru.

Mutohir, Toho Cholik. (2002). Gagasangagasan tentang pendidikan jasmani dan olahraga. Surabaya: Unesa University Press.

Nasution. (2012). Kurikulum \& pengajaran. Jakarta: Bumi Aksara.

Nawawi, Hadari \& Hadari, Martini. (2006). Instrumen penelitian bidang sosial. Yogyakarta: Gadjah Mada University Press.

Nurhasan. (2001). Tes dan pengukuran dalam pembelajaran pendidikan jasmani. Jakarta: Direktorat Jendral Olahraga.

Rocmah, Luluk Iffatur. (2012). Model pembelajaran outbond untuk anak usia dini. Jurnal Pedagogia. UMS Vol. 1, No. 2, 173-188.

Ramli. (2005). Pendampingan perkembangan anak usia dini. Jakarta: Depdiknas.

Sugiyono. (2009). Metode penelitian pendidikan, pendekatan kuantitatif, kualitatif dan $R \quad \& \quad D$. Bandung: Alfabeta.
Sugiyono. (2010). Metode penelitian administrasi. Bandung: Alfabeta.

Sugiyono. (2013). Metologi penelitian kuantitatif, kualitatif, dan research and development. Bandung: Alfabeta.

Suparlan. (2008). Membangun sekolah efektif. Yogyakarta: Hikayat.

Supendi, Pepen \& Nurhidayat. (2007). 50 Permainan menyenangkan di indoor \& outdoor. Jakarta: Penebar Swadaya.

Suyatno. (2006). Metode pembelajaran outbound. Mojokerto: FIK. UNESA.

Putri, Vincencia Septaviani Issera Sulistya. (2006). Mendidik generasi muda dengan pendidikan lingkungan. http:/rafflesia.wwf.or.id/library/clips/cli ps_detil.php?id_clips=2. Diakses: 01 November 2013.

Weinberg, R. S. \& Gould, D. (2003). Foundations of sport and exercise psychology, (3 $\left.{ }^{\text {th }} e d.\right)$. Champaign, IL: Human Kinetics.

Wong, D. L. (2008). Buku ajar keperawatan pediatrik.

EGC 